\title{
A New Method for the Determination of Cyanide Ions and Their Quantification in Some Senegalese Cassava Varieties
}

\author{
Younoussa Diallo $^{1 *}$, Momar Talla Gueye ${ }^{1}$, Cheikh Ndiaye $^{1}$, Mama Sakho $^{2}$, Amadou Kane ${ }^{1}$, \\ Jean Paul Barthelemy ${ }^{3}$, Georges Lognay ${ }^{3}$ \\ ${ }^{1}$ Institut de Technologie Alimentaire, Route des Pères Maristes, Dakar, Sénégal \\ ${ }^{2}$ Département Génie Chimique et Biologie Appliquée, Ecole Supérieure Polytechnique, \\ Université Cheikh Anta Diop de Dakar, Dakar, Sénégal \\ ${ }^{3}$ Unité Analyses, Qualité, Risques et Laboratoire de Chimie Analytique, Gembloux Agro-Bio Tech, \\ Université de Liège, Gembloux, Belgique \\ Email: yunusdiallo@gmail.com
}

Received December 26, 2013; revised January 28, 2014; accepted February 5, 2014

Copyright (C) 2014 Younoussa Diallo et al. This is an open access article distributed under the Creative Commons Attribution License, which permits unrestricted use, distribution, and reproduction in any medium, provided the original work is properly cited. In accordance of the Creative Commons Attribution License all Copyrights (C) 2014 are reserved for SCIRP and the owner of the intellectual property Younoussa Diallo et al. All Copyright (C) 2014 are guarded by law and by SCIRP as a guardian.

\begin{abstract}
Cassava (Manihot esculenta Crantz) is a starchy staple food that previous researches have showed to contain cyanogenic compounds, precursors of hydrocyanic acid, undoubtedly toxic for humans. With the aim to determine food security in cassava, this study developed a simple, fast and less expensive step for quantifying cyanide ions by using micro-diffusion with modified Conway cells. After an enzymatic degradation, the cyanide ions were quantified by electrochemical procedures. The validation of this method is estimated. The concentration of cyanide ions at different part of the samples was determined. The results showed high toxicity in some fresh Senegalese consumed cassava varieties $\left(>100 \mathrm{mg} \mathrm{HCN} \cdot \mathrm{kg}^{-1}\right)$. However, in the processed cassava products, less than 10 $\mathrm{mg} \mathrm{HCN} \cdot \mathrm{kg}^{-1}$ was found in the different varieties studied except for the chips where the levels of $\mathrm{CN}^{-}$contents were important $\left(>49 \mathrm{mg} \mathrm{HCN} \cdot \mathrm{kg}^{-1}\right)$.
\end{abstract}

\section{KEYWORDS}

Cassava; Cyanogenic Glycosides; Cyanide Ion; Micro-Diffusion; Toxicity

\section{Introduction}

More than half of billion people consume cassava (Manihot esculenta Crantz), which is mainly grown and used for its roots and leaves [1]. According to [2], 56 percent of world production or around 145 million tons of cassavas were grown in Africa during 2011. Cassava contains cyanogenic glycosides, mostly linamarin ( $2-\beta$-D-glucopyranosyloxy-2-methylpropanenitrile) and lautostralin (2$\beta$-D-glucopyranosyloxy-2-methylbutyronitrile) [3]. These glycosides are supposed not to be toxic, but their decomposition into hydrogen cyanide ( $\mathrm{HCN})$ by intestinal flora enzymes would take place if humans ingested them [4]. The produced HCN is toxic for humans and it was reported to be responsible for certain pathological disorders such as Konzo diseases, thyroid goiter and tropical

\footnotetext{
"Corresponding author.
}

ataxic neuropathy [5]. In order to develop strategies to deal with preventing further outbreaks of these illnesses, it's important to have efficient methods and evaluate the cyanogenic potential of cassava fresh roots and its derivate products.

In fact, cyanogenic glycosides are generally measured through titrimetric, electrochemical or colorimetric methods. The choice of procedure would then depend only on the concentration of cyanide in the sample solution. According to [6], titrimetric methods are suitable for the determination of concentration of ionic cyanide above 1 $\mathrm{mg} \cdot \mathrm{l}^{-1}$, procedures involving the use of electrochemical cover the range from 0.05 to $10 \mathrm{mg} \cdot \mathrm{l}^{-1}$, and with colorimetric methods, one is able to detect concentration as low as $20 \mu \mathrm{g} \cdot \mathrm{l}^{-1}$. The use of endogenous linamarase to achieve electrochemical methods is developed in this paper. 
Moreover, people in some West Africa countries (Ivory Coast, Benin, and Nigeria) have quickly realized the need of transforming cassava in its derivate byproducts whose value added is generally higher than that of the fresh roots. In fact, traditional methods including grating and soaking by natural fermentation followed by direct sun-dry- ing have potentialities to significantly reduce the HCN content [7]. The provided derivate products met best storage conditions, reduced transport costs due to lower weight products, and improved nutritional value and good taste especially after fermentation.

In Senegal, after the recent sustained increases of cassava production from 182,494 $\mathrm{t}$ in 2003 to $920,866 \mathrm{t}$ in 2008, it declined to $154,879 \mathrm{t}$ in 2011 [2]. That is related to several factors among others: the scarcity of rainfall, the deficit crop plant protection, the insufficient adapted post-harvest conservation and processing technologies, the deficient added value [8]. Furthermore, Senegalese varieties are facing lacks of information on their toxicological properties as well as processing technology previously mentioned. Therefore, the objective of this study was to develop a simple and effective procedure for analyzing cyanide ions and contributing to toxicity studies on Senegalese cassava varieties. The procedure in this present paper relies on many of associated advantages easily applicable in developing countries.

\section{Materials and Methods}

\subsection{Plant Material}

Two local varieties "Soya and Gnargui" with an introduced variety "TMS 30572" were used in this present study. Soya and Gnargui are the most common varieties regarding their production in what might be called "Senegal cassava area" located at "Tivaouane" town in the “Thies” region (14 $\left.47^{\prime} 26^{\prime \prime} \mathrm{N}, 16^{\circ} 55^{\prime} 29^{\prime \prime} \mathrm{W}\right)$. This area provides more than 75 per cent of the Senegalese cassava production in 2011 [9]. According to [10], TMS 30572 is widely preferred and adopted among 24 Nigerian varieties because of its high yield, early maturity and disease resistance.

The samples were harvested from 20 months plants old in this previous cited area.

\subsection{Sample Preparation}

\subsubsection{Fresh Material}

For every considered variety, samples of leaves, stems and roots were took from the same plant and directly transported to the laboratory in the same day using containers with ice to keep them fresh before any processing.

Each harvested part of the plant was fragmented into small pieces, and then immersed in nitrogen liquid before grinded, homogenized and placed in plastic vial as sample. These samples were freeze at $-20^{\circ} \mathrm{C}$ for further analysis.

\subsubsection{Cassava Derivative Products}

Cassava derivate products were obtained using artisanal and semi-industrial processes to closely reflect the way that people consume these products. In this study, the selected products were Chips, Flour, Gari and Attieke. The resumed processing technology for every product is mentioned as follows:

Chips: the roots were peeled, washed and cut into small pieces $(0.6<\varnothing<1.8 \mathrm{~cm})$ and then sun dried.

Flour: the roots were peeled, washed and crushed. The crushed and pressed extracted pulp was sun dried. The dried pulp was grind and sieved through a $710 \mu \mathrm{m}$ sieve.

Gari: the roots were peeled, washed and crushed. Then the slurry was fermented for 48 hours before pressed. The obtained pulp was sieved and dried using stainless cooking devices.

Attieke: the roots were peeled, washed, crushed and fermented for 48 hours before pressed. The obtained pulp was rolled, sifted then steamed.

The Attieke was freeze $\left( \pm 4^{\circ} \mathrm{C}\right)$, while the dried products such as Chips, Flour and Gari were stored at room temperature $\left(18^{\circ} \mathrm{C}-32^{\circ} \mathrm{C}\right)$.

\subsection{Methods for Determination of Total Cyanide}

Electrochemical procedures were conducted using a steam distillation accepted as standard method of the American Organization for Analytical Chemistry (AOAC) [11] and a micro-diffusion step with modified Conway cells firstly tested on cassava according to the literature review.

Linamarin and Linamarase were provided by the Analytical Chemical Laboratory of Gembloux Agro-BioTech in Belgium, stock solutions and reagents were of analytical grade and prepared as follows:

1) $\mathrm{K}_{2} \mathrm{CO}_{3} 1 \mathrm{M}: 69 \mathrm{~g}$ of Potassium Carbonate was mixed in $500 \mathrm{ml}$ distilled water;

2) Standard solution $\left(\mathrm{CN}^{-} / \mathrm{K}_{2} \mathrm{CO}_{3} 0.1 \mathrm{M}\right) 1000 \mathrm{ppm}$ : $0.2503 \mathrm{~g}$ of Potassium Cyanide was added to $10 \mathrm{ml}$ of $\mathrm{K}_{2} \mathrm{CO}_{3}$ solution $1 \mathrm{M}$ and complete to $100 \mathrm{ml}$ with distilled water.

2.3.1. Principle and Procedure Used in the Distillation Distillation was essayed according to [12] with some modifications on the enzymatic method used. Hydrocyanic acid was produced by acting endogenous linamarase, a natural occurring enzyme, on cyanogenic glycosides both presented in cassava roots. Thereafter, the cyanide ions were distilled and evaluated by using potentiometric measurement with selective electrode $\mathrm{CN}$ ions.

One gram of sample was mixed with $20 \mathrm{ml}$ of a buffered sodium acetate solution $(0.1 \mathrm{M}$ acetate buffer and chloramphenicol $\left.0.1 \mathrm{mg} \cdot \mathrm{mol}^{-1}\right)$, $\mathrm{pH}=5.5 \mathrm{in} 100 \mathrm{ml}$ pe- 
nicillin flask. The vials were sealed and incubated for 17 hours (tested necessary incubation time to degrade all of the cyanide contained in the sample) at $37^{\circ} \mathrm{C}$.

When the incubation time was over, $4 \mathrm{ml}$ of $\mathrm{NaOH} 1$ $\mathrm{M}$ were added to the previous solution using a syringe in order to fix the cyanide $\mathrm{CN}$ ions onto nonvolatile forms.

The aliquots were then transferred into a balloon distiller. The bubbler for recovering the vapor of cyanide contained $5 \mathrm{ml}$ of $\mathrm{K}_{2} \mathrm{CO}_{3}$ solution $1 \mathrm{M}$. The distillation was operated, then $10 \mathrm{ml}$ of $\mathrm{H}_{2} \mathrm{SO}_{4}$ solution $10 \%$ were introduced into the flask, and continued for another 15 min (tested necessary distillation time to evaporate all of the cyanide contained in the sample). The solution in the bubbler was transferred into a $50 \mathrm{ml}$ vial and complete to volume with distilled water.

\subsubsection{Principle and Procedure Used in the Micro-Diffusion Step}

The released hydrocyanic acid was obtained through the action of linamarase enzyme already present in cassava and activated under the effect of the buffered sodium acetate. The cyanide ions were captured directly by a solution of potassium carbonate $\left(\mathrm{K}_{2} \mathrm{CO}_{3}\right) 1 \mathrm{M}$.

The prototype of Conway cells used is schematically represented in Figure 1. The prototype was replaced by a plastic container unlike the original Pyrex glass mostly fragile and different in size. The design looked like a small Petri dish with two chambers; one outer and another inner. Silicone grease was applied to the rim of the lid to facilitate its closure after being sealed.

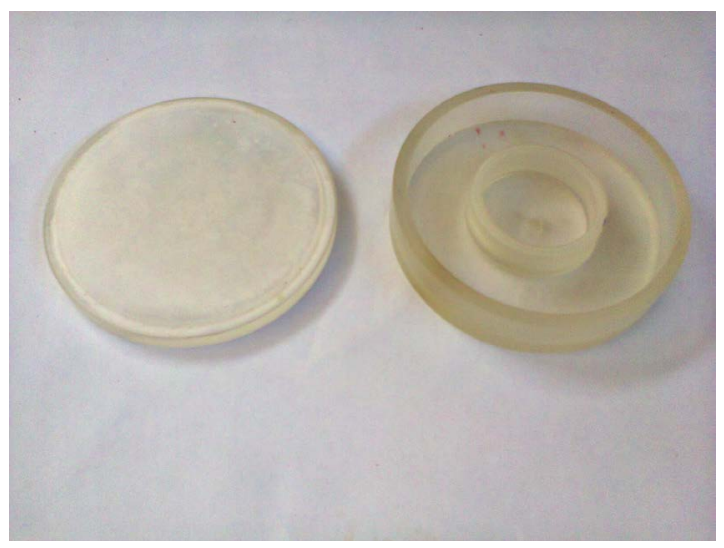

(a)

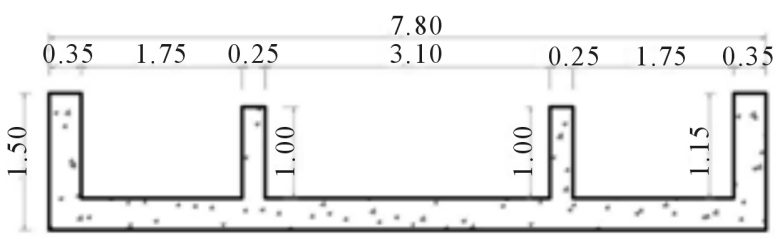

(b)

Figure 1. Modified Conway cell (plastic nature): (a) Overview and (b) Cross-section.
One gram of sample was placed in the outer chamber and $3 \mathrm{ml}$ of $\mathrm{K}_{2} \mathrm{CO}_{3} 1 \mathrm{M}$ is placed in the inner chamber. Then $10 \mathrm{ml}$ of the buffered sodium acetate solution was added to the sample (in the outer chamber) and the cell was immediately sealed and incubated at $37^{\circ} \mathrm{C}$ for 17 hours.

Meanwhile the incubation time was achieved; the solution in the inner chamber $\left(\mathrm{K}_{2} \mathrm{CO}_{3}+\right.$ captured $\left.\mathrm{CN}^{-}\right)$was recovered using a Pasteur pipette in a $50 \mathrm{ml}$ vial. Then the inner chamber was flushed with $2 \mathrm{ml}$ of $\mathrm{K}_{2} \mathrm{CO}_{3} 1 \mathrm{M}$ and the vial was completed to volume with distilled water.

NB: For the samples of cassava derivate products, 1 $\mathrm{ml}$ of linamarase (a solution of $0.0213 \mathrm{~g}$ in $25 \mathrm{ml}$ distilled water) was added before incubation. Verification was done by incubation tests on pure linamarin to find out if the amount of enzyme was sufficiently enough to degrade all linamarin samples. For recovery tests, $1 \mathrm{ml}$ of linamarin $(105.23 \mu \mathrm{g} \mathrm{CN})$ was added before incubation.

\subsubsection{Potentiometric Measurement and \\ Determination of Total Cyanide Content}

Standard solutions $\left(\mathrm{CN}^{-} / \mathrm{K}_{2} \mathrm{CO}_{3} 0.1 \mathrm{M}\right) 0 \mathrm{ppm}$; $0.5 \mathrm{ppm}$; 1 ppm; 2 ppm; 3 ppm; 5 ppm and 10 ppm were prepared from a cyanide solution of $1000 \mathrm{ppm}$ in order to determine the calibration curve.

The reading of standard and sample solutions was achieved using a spectrophotometer UV-1205 at $580 \mathrm{~nm}$ (Shimadzu, France); a 500D Nanocolor ${ }^{\circledR}$ MN Tests 1 30 (Macherey-Nagel GmbH \& Co.KG, Germany) and a polarography (Metrohm, France). The polarographic analysis has been widely used as a laboratory tool for its availability.

A differential mode of polarographic pulse was performed using the standards solutions. Each solution was transferred into a cell in which were immersed three electrodes including a working electrode mercury, a reference electrode $(\mathrm{Ag} / \mathrm{AgCl})$, and an auxiliary electrode (platinum wire). Before any potentiometric measurement, the oxygen dissolved in each solution was removed by nitrogen bubbling for $4 \mathrm{~min}$.

The obtained polarogram, characterized by the peak height $(H)$, was proportional to cyanide ions concentration. The intensity of the polarogram was determined using Equation (1). The concentration $(C)$ was derived from the calibration curve using the measured intensity in (1). The cyanide ion content (T) $\left(\mathrm{mg} \cdot \mathrm{kg}^{-1}\right)$ of the sample was determined using Equation (2).

$$
\begin{aligned}
I & =(S \times H) / L \\
T & =(C \times V) / W S
\end{aligned}
$$

where $I$ = polarogram intensity (uA), $S=$ polarography sensitivity (uA), $H$ = peak height (cm), $L=$ paper height $(\mathrm{cm}), T=$ cyanide ion content $(\mathrm{mg} / \mathrm{kg}), C=$ concentra- 
tion of solution $\left(\mathrm{g} \cdot \mathrm{ml}^{-1}\right), V=$ volume of vial $(\mathrm{ml}), W S=$ weight of sample (g).

\subsection{Data Processing}

A general linear model (ANOVA) was applied to the data and compared thereafter to Student-Neuwman-Keuls test $(\mathrm{p}<0.05)$ using XLSTAT 6.1.9.

\subsection{Validation of the Micro-Diffusion Assay}

The procedure of validation was in perfect conformity with the Quality System of Good Laboratory Practice (GLP) at the Analytical Chemical Laboratory of Gembloux Agro-Bio-Tech (Belgium). To estimate the selectivity of the instruments response, comparing measurement on sample only and on sample with addition of a cyanide solution (500 $\left.\mu \mathrm{l} \mathrm{CN}^{-} 100 \mathrm{ppm}\right)$ was performed. Student-Neuwman-Keuls test was applied for the statistical means test using $\mathrm{p}=0.975$ and $\mathrm{k}=2(\mathrm{~N}-1)=6$. The lack of matrix effect is obtained if $\mathrm{T}_{\text {observed }}<\mathrm{T}_{0.975}=$ 2.447. If matrix effect is present (non-selective response), results with addition of cyanide solution have to be considered. The linearity was established by using a variance statistical test based on the three lines of calibration curve and resulting from the same solution. According to [13], the linearity was accepted if the corresponding $F$ values would be criticized by the obtained value at 0.95 confidence degree with 4 and 12 degree of freedom as lower than 3.26 (F distribution table of Snedecor). For an F value higher than 3.26 , the linearity can be accepted only if the determined coefficient $\mathrm{R}^{2}$ is equal or higher than 0.996. The accuracy (recovery test) of solutions might show an error lower or higher than $10 \%(90 \%$ $110 \%$ ). For accepted repeatability test, the coefficient of variation (CV) would be less than 4\% [14]. The limits of detection (LOD) and quantification (LOQ) were evaluated by the measurement of five analyses of the blank. LOD $=$ Average of noise background $+5 \times$ Standard Deviation. LOQ $=$ Average of noise background $+10 \times$ Standard Deviation.

\section{Results and Discussion}

\subsection{Validation of the Micro-Diffusion Assay}

\subsubsection{Method Selectivity/Matrix Effect}

The results obtained $\mathrm{T}_{\text {observed }}$ is $0.6242(<2.447)$ indicate that no significant matrix effect was found, and therefore the polarographic instrument response was considered selective.

\subsubsection{Linearity Study}

The repeatability and reproducibility results were presented in Tables 1 and 2 respectively.

The results in Tables 1 and 2 showed good repeatabil-
Table 1. Results of repeatability.

\begin{tabular}{ccc}
\hline Repeatability Test & $\mathrm{CN}^{-}$content $\left(\mathrm{mg}^{\mathrm{kg}}{ }^{-1}\right) /$ Fresh Material \\
\hline Measures & Var.1 & Var.2 \\
$\mathrm{m} 1$ & 245.92 & 215.19 \\
$\mathrm{~m} 2$ & 249.23 & 205.58 \\
$\mathrm{~m} 3$ & 263.27 & 219.35 \\
$\mathrm{~m} 4$ & 253.51 & 216.23 \\
$\mathrm{~m} 5$ & 257.29 & 219.73 \\
Mean \pm SD & $253.84 \pm 6.80$ & $215.21 \pm 5.73$ \\
$\mathrm{CV}$ & $2.68 \%$ & $2.66 \%$ \\
\hline
\end{tabular}

Table 2. Results of reproducibility for $10 \mathrm{ppm} \mathrm{CN}^{-} / \mathrm{K}_{2} \mathrm{CO}_{3}$ 0.1 M standard solution.

\begin{tabular}{cccc}
\hline $\begin{array}{c}\text { Reproducibility } \\
\text { Test }\end{array}$ & \multicolumn{3}{c}{ Standard Solution } \\
\hline 4-sept & 951.5 & - & - \\
5-sept & 1016 & 1002 & - \\
6-sept & 962.3 & 985.7 & 981.4 \\
9-sept & 950.3 & 952.7 & 949.4 \\
Mean \pm SD & $970.03 \pm 31.12$ & $980.13 \pm 25.12$ & $965.40 \pm 22.63$ \\
CV & $3.21 \%$ & $2.56 \%$ & $2.34 \%$ \\
\hline
\end{tabular}

ity and reproducibility because all CV were found below $4 \%$ which fulfilled the requirements of our GPL validation procedures.

Moreover, the LOD and LOQ were 1.38 and 1.8 $\mu \mathrm{g} \cdot \mathrm{g}^{-1}$ respectively. The calibration curve is shown in Figure 2. The linearity can be accepted but the coefficient of determination $\mathrm{R}^{2}=0.9981$ is higher than 0.996 .

The result (mean $\pm \mathrm{SD}$ ) of five experimental measurements, performed for recoveries tests, was $98.62 \% \pm$ $2.08 \%$, is between $90 \%-110 \%$ as recommended by validation procedures. This result indicated that samples had contained enough enzymes, necessary to degrade the linamarin content.

In consideration of all these aspects, we can clearly state that the micro-diffusion with Conway cells used as new technical essay was appropriate as it met the criteria of validated chemical analyses. According to [14], the results can confirm the adaptation of the micro-diffusion step used in this study to accurately perform the measure of cyanide ions content in starchy staples such as cassava.

\subsection{Comparison Results between the Distillation Used and the Micro-Diffusion}

Distillation and micro-diffusion procedures results are represented in Table 3 for the analyzed cassava varieties.

From Table 3, no significant difference was found between the amounts of $\mathrm{CN}^{-}$obtained either by distilla- 


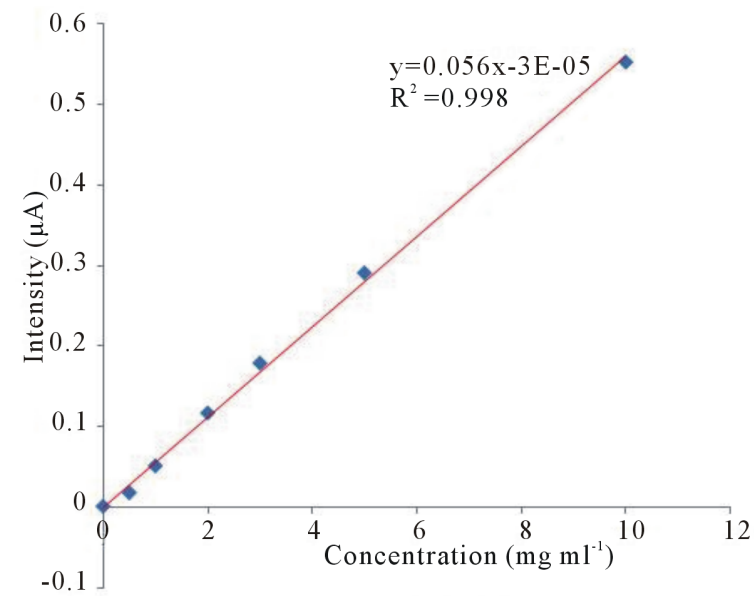

Figure 2. Polarographic analysis of $\mathrm{CN}^{-}$standard solutions.

Table 3. $\mathbf{C N}^{-}$content $\left(\mathrm{mg}^{\circ} \mathbf{k g}^{-\mathbf{1}}\right)$ of fresh cassava peeled root $($ Mean $\pm S D, n=5)$.

\begin{tabular}{ccc}
\hline & $\mathrm{CN}^{-}$content $\left(\mathrm{mg} \cdot \mathrm{kg}^{-1}\right)^{*}$ Fresh material \\
\hline Varieties & Distillation & Micro-diffusion \\
var.1 & $217.81 \mathrm{a} \pm 19.02$ & $218.92 \mathrm{a} \pm 7.30$ \\
var.2 & $226.74 \mathrm{~b} \pm 5.55$ & $225.13 \mathrm{~b} \pm 9.99$ \\
\hline
\end{tabular}

"Means followed by the same alphabetical letters are statistically homogeneous, $\mathrm{p}<0.05$.

tion or micro-diffusion procedures. According to [6], distillation procedures are relatively time consuming and inadequate for the routine analysis of large samples numbers. Indeed, unlike distillation process, micro-diffusion step was simple, fast, and could allow many measurements at once by eliminating interferences that might occur. The micro-diffusion assay used in this study would be an alternative procedure of $\mathrm{CN}^{-}$quantification in cassava and other crops for many countries because of the low cost used material (Conway cells) compared to distiller equipment.

According to the results mentioned above, the possibility of analyzing different samples from cassava plant using the micro-diffusion step was performed.

\section{3. $\mathrm{CN}^{-}$Contents $\left(\mathrm{mg}^{\circ} \mathrm{kg}^{-1}\right)$ of Different Samples from Cassava Plant}

The results on fresh leaf, stem, root peel, and root flesh samples of some Senegalese cassava varieties are presented in Table 4.

Significant presence of cyanide content in all parts of cassava plant samples was found in the studied varieties (Table 4). Classification was referred on fresh peeled roots as reported by previous papers in order to assess the toxicity of cassava. Thus, varieties with less than $50 \mathrm{mg}$ $\mathrm{HCN} \cdot \mathrm{kg}^{-1}$ were "harmless", 50 to $100 \mathrm{mg} \mathrm{HCN} \cdot \mathrm{kg}^{-1}$ were "moderately toxic" and more than $100 \mathrm{mg} \mathrm{HCN} \cdot \mathrm{kg}^{-1}$ were "highly toxic" [15]. According to the previous classification, the fresh peeled cassava varieties' roots in this study were highly toxic $\left(>100 \mathrm{mg} \mathrm{HCN} \cdot \mathrm{kg}^{-1}\right)$. Indeed, no classification for $\mathrm{CN}^{-}$content on other parts of cassava plant (leaf, stem) is available and there are no correlations among leaves, stems and roots on $\mathrm{CN}^{-}$content [16]. According to [17], the $\mathrm{CN}^{-}$content varies with agro-ecological conditions, harvest period, plant organ, age, and variety. Previous reports showed that the transfer of cassava genotypes from one locality to another could change the amount of cyanogenic compounds in fresh roots due to climate changes and soil characteristics [18]. The same conclusion was found in some Nigerian varieties, according to [19].

The effects of processing unit operations on reducing $\mathrm{CN}^{-}$contents were studied on cassava derivate products. The results are shown in Table 5 .

In dehydrated products such as Flour, Gari and Attieke, the reduction of $\mathrm{CN}^{-}$content is crucial before any acceptability. The $\mathrm{CN}^{-}$residues found in our developed products were all less than $10 \mathrm{mg} \mathrm{HCN} \cdot \mathrm{kg}^{-1}$ which is the safe level recommended by the Codex Alimentarius Committee of the FAO/WHO [20]. However, in chips' samples, the levels of $\mathrm{CN}^{-}$contents were 49;57 and $83 \mathrm{mg}$ $\mathrm{HCN} \cdot \mathrm{kg}^{-1}$ for Soya, TMS 30572 and Gnargui, respectively. These values exceeded the standard set by the FAO/WHO as human food. In fact, cassava tubers preliminary operations such as washing, cutting and drying removed easily the free cyanide while the glucosidic cyanide, slowly hydrolyzed by endogenous enzyme, might be responsible for the important residue as observed in the chips [21].

The results in cassava derivate products showed that pre-treatment processes reduced drastically the initial level of cyanide ions content. It is also important to point out that additional operations including fermentation and cooking contributed positively on reducing $\mathrm{CN}^{-}$contents in Attieke and Gari which had a lower residual content (Table 5). This suggests that processing parameters include mode, time and cooking temperature have a great influence on decreasing the cyanide ions content levels in our different products. These results confirm the effect of traditional methods to reduce initial $\mathrm{CN}^{-}$content through processes such as grating, soaking and cooking used for making these cited products. However, the reduction level in every process would depend on sample quality, processing technology and the part of plant used.

\section{Conclusions}

Many methods, as costly laboratory equipment, have been previously developed to determine the cyanide ion contents. Some developing countries, where cassava is widely consumed, find difficulties in measuring the total cyanide ion content in their fresh cassava and byproducts. 
Table 4. Fresh material $\mathrm{CN}^{-}$content $\left(\mathrm{mg} \cdot \mathrm{kg}^{-1}\right)^{*}$ of different sample from cassava plant $(\mathrm{Mean} \pm S D, \mathbf{n}=5)$.

\begin{tabular}{ccccc}
\hline Varieties & Leaf & Stem & Root peel & Root flesh \\
\hline TMS 30 572 & 187.30a $( \pm 24.57)$ & $183.83 \mathrm{c}( \pm 11.84)$ & $127.63 \mathrm{f}( \pm 6.0)$ & $110.49 \mathrm{~h}( \pm 13.03)$ \\
Soya & $148.81 \mathrm{~b}( \pm 9.15)$ & $163.62 \mathrm{~d}( \pm 5.90)$ & $368.55 \mathrm{~g}( \pm 22.0)$ & $323.47 \mathrm{i}( \pm 6.13)$ \\
Gnargui & $192.54 \mathrm{a}( \pm 17.74)$ & $230.69 \mathrm{e}( \pm 9.10)$ & $354.51 \mathrm{~g}( \pm 20.53)$ & $189.12 \mathrm{j}( \pm 4.0)$ \\
\hline
\end{tabular}

*In the same column, means followed by different alphabetical letters are statistically heterogeneous, $\mathrm{p}<0.05$.

Table 5. Dry material $\mathrm{CN}^{-}$content $\left(\mathrm{mg} \cdot \mathrm{kg}^{-1}\right)$ of Chips, Flour, Gari and Attieke made from our cassava varieties (Mean, $n=3)$.

\begin{tabular}{ccccc}
\hline Derivate products & Chips & Flour & Gari & Attieke \\
\hline TMS 30 572 & 57.0 & 3.1 & 2.0 & 6.0 \\
Soya & 49.0 & $\mathrm{Nd}$ & $\mathrm{Nd}$ & 3.9 \\
Gnargui & 83.0 & $\mathrm{Nd}$ & $\mathrm{Nd}$ & 2.0 \\
\hline
\end{tabular}

Nd = Not detected.

This article provided an inexpensive step and well adapted for performing electrochemical analyses.

Our results indicate that some varieties currently produced and largely consumed in Senegal need to be paid more attention to on their use as food or feed. Indeed, processing unit operations should be well conducted and optimized for healthy products with minor or no potential danger for consumers.

Further studies involving variation in seasons and agro-ecological conditions could provide complete toxicological characterizations and edify the quality status of cassava derivate products. It would be also appropriate to stand for good processing practices used in cassava varieties and developed by genetic manipulations in order to produce safe cassava products.

\section{Acknowledgements}

This work was conducted with financial support from the World Bank through the West Africa Agricultural Productivity Program (WAAPP). The Authors would like to thank Serge Guede and Farah Darbouche for their technical contribution.

\section{REFERENCES}

[1] J. H. Cock, "Cassava: New Potential for a Neglected Crop,” Westview Press, Boulder, 1985, p. 191.

[2] FAOSTAT, 2013. http://faostat.fao.org/site/339/default.aspx

[3] C. A. Idible, "Isolation of Pure Cassava Linamarin as an Anti Cancer Agent,” Master of Science in Engineering, University of the Witwatersrand, Faculty of Engineering and the Built Environment, Johannesburg, 2006, 109 p.

[4] E. A. Ouegnin, “Contribution à L'étude de L'acide Cyanhydrique dans un Produit de Transformation du Manioc:
L’Attiéké,” Thèse de Doctorat en Pharmacie, Université Cheikh Anta Diop de Dakar, Sénégal, No. 22, 1988.

[5] S. C. Kobawila, D. Louembe, S. Keleke, J. Hounhouigan and C. Gamba, "Reduction of the Cyanide Content during Fermentation of Cassava Roots and Leaves to Produce Bikedi and Ntobambodi, Two Food Products from Congo,” African Journal of Biotechnology, Vol. 4, No. 7, 2005, pp. 689-696.

http://www.ajol.info/index.php/ajb/article/view/15168/59 $\underline{486}$

[6] C. Pohlandt, E. A. Jones and A. F. Lee, "A Critical Evaluation of Methods Applicable to the Determination of Cyanides," Journal of the South African Institute of Mining and Metallurgy, Vol. 83, 1983, pp. 11-19.

[7] M. Ernesto, A. P. Cardoso, D. Nicala, E. Mirione, F. Massaza, J. Cliff, M. R. Haque and J. H. Bradbury, "Persistent Konzo and Cyanide Toxicity from Cassava in Northern Mozambique," Acta Tropica, Vol. 82, No. 3, 2002, pp. 357-362.

http://dx.doi.org/10.1016/S0001-706X(02)00042-6

[8] Y. Diallo, M. T. Gueye, M. Sakho, P. B. Darboux, A. Kane, J.-P. Barthelemy and G. Lognay, "Importance Nutritionnelle du Manioc et Perspectives pour L'alimentation de base au Sénégal-Synthèse Bibliographique," Biotechnology, Agronomy, Society and Environment, Vol. 17, No. 4, 2013, pp. 634-643.

[9] ANSD (Agence Nationale de la Statistique et de la Démographie), "Bulletin Mensuel des Statistiques Economiques,” Dakar: DAPS/MA, 2011, p. 8.

http://www.ansd.sn/publications/conjoncturelles/...statisti que/BullStat 10 11.pdf

[10] A. A. Adeniji, L. A. Ega, M. O. Akoroda, B. O. Ugwu and A. Balogum, "Global Strategy for Cassava Development. Nigeria: A Country Case Study,” Department of Agriculture, Federal Ministry of Agriculture and Natural Resources, Available Developments of New Techniques for Pari Production, 2001. http://www.globalcassavastrategy.net

[11] S. Williams, "Hydrocyanic Acid in Beans, Alkaline Titration Method," Official Methods of Analysis of the Association of Official Analytical Chemist, AOAC, Inc., Arlington, 1990, p. 1213.

[12] J. P. Baudoin, J. P. Barthelemy and V. Ndungo, "Cyanide Production of the Lima Bean, Phaseolus lunatus L.: Genetic Variability in the Primary and Secondary Gene Pools and in Some Intraspecific Hybrid," Bulletin de Recherche Agronomique de Gembloux, Vol. 26, No. 3, 1991, pp. 367-388.

[13] M. T. Gueye, D. Seck, A. Diallo, D. Trisman, C. Fischer, J. Barthelemy, J. Wathelet and G. Lognay, "Development 
of a Performant Method for Glucocapparin Determination in Boscia senegalensis Lam Ex. Poir.: A Study of the Variability," American Journal of Analytical Chemistry, Vol. 4, No. 2, 2013, pp. 104-110.

http://dx.doi.org/10.4236/ajac.2013.42014

[14] J. P. Barthelemy and P. Maesen, "Validation des Méthodes Analytiques,” Validana. P02, BPL, 2013, 34 p.

[15] G. Yeo, "Potentialités à la Transformation du Manioc en Afrique de l'Ouest,” In: G. Amani, C. Nindjin, B. N'zue, A. Tschannen and D. Aka, Eds., Potentialités à la Transformation du Manioc en Afrique de l'Ouest, Actes Atelier Abidjan, Côte d'Ivoire, 4-7 June 2007, pp. 48-79.

[16] M. Bokanga, "Distribution of Cyanogenic Potential in Cassava Germplasm,” Acta Horticulturae (ISHS), Vol. 375, 1994, pp. 117-123.

http://www.actahort.org/books/375/375 9.htm

[17] A. Nzigamasabo and Z. H. Ming, “Traditional Cassava Foods in Burundi: A Review," Food Reviews Interna- tional, Vol. 22, No. 1, 2006, pp. 1-27. http://dx.doi.org/10.1080/87559120500379761

[18] IITA, “Archival Report (1989-1993). Part 1. Cassava Breeding, Cytogenetics and Histology,” Vol. 2, Germplasm Enhancement, Crop Improvement Division, TRIP (Tuber Root Improvement Program), IITA, Ibadan, 1993.

[19] M. Bokanga, I. J. Ekanayake, A. G. O. Dixon and M. C. M. Porto, "Genotype-Environment Interaction for Cyanogenic Potential in Cassava,” Acta Horticulturae (ISHS), Vol. 375, 1994, pp. 131-140.

http://www.actahort.org/books/375/375_11.htm

[20] FAO/WHO, “Joint FAO/WHO Food Standards Program,” Codex Alimentarius Commission XII, Supplement 4, 1991, Rome.

[21] Y. Diallo, M. T. Gueye, P. B. Darboux, S. Guede, A. Kane and J. P. Barthelemy, "Des Traitements Technologiques pour Eliminer la Toxicité du Manioc,” Itaechos, Vol. 7, 2013, pp. 10-11. 